\title{
The Impact of CEMAC Bilateral Trade on the Economic Growth of Cameroon: Evidence from the Augmented Solow Model
}

\author{
Metougue Esoh Ekwelle Eric ${ }^{1 *} \quad$ Molem Sama $^{2} \quad$ Dobdinga Cletus ${ }^{3}$ \\ 1. Doctoral Candidate, University of Buea, Cameroon \\ 2. Professor in Economics, University of Buea, Cameroon \\ 3. Associate Professor in Economics, University of Buea, Cameroon
}

\begin{abstract}
Economists view international trade as an engine to the economic growth of nations. Specifically, international trade is believed to promote the efficient allocation of resources, allows countries to experience the benefits of scale, facilitates the diffusion of knowledge, fosters technological progress and encourages competition. As a result, policy makers continue to undertake socio-economic, legal, political and institutional reforms in order to boost international trade. The study examines the impact of bilateral trade in the Economic and Monetary Union of Central African States (CEMAC) on the economic growth of Cameroon for a forty six year period from 1972 to 2018 using data collected from the World Bank and the International Monetary Fund. Through the adoption of the Poisson Pseudo Maximum Likelihood Estimator (PPML), the study finds out that while Cameroon's bilateral trade with other CEMAC member States had an insignificant impact on the economic growth of Cameroon. Also, total labour force, government investment in education, government investment in fixed capital and the creation of CEMAC as a trade bloc all have a positive impact on the economic growth of Cameroon. The study recommends that policy makers in Cameroon and the CEMAC region as a whole should put in place laws, policies, measures and structures that boost bilateral trade within the CEMAC region in a bid to foster the economic growth of Cameroon as well as the economic growth of the CEMAC region as a whole.
\end{abstract}

Keywords: International trade, Economic growth, CEMAC, Poisson Pseudo Maximum Likelihood (PPML) Estimator.

DOI: $10.7176 / \mathrm{JESD} / 11-10-19$

Publication date:May $31^{\text {st }} 2020$

\section{Introduction}

A more general consensus among Economists is that international trade acts as an engine to the economic growth of nations. The empirical works of Barro and Sala-i-Martin (1997), Baldwin et al. (2005), Almeida and Fernandes (2008), Alesina et al. (2000), Bond et al. (2005) and Grossman and Helpman (1991) amongst many other authors establish a clear positive link between international trade and economic growth.

More specifically, according to these authors, international trade is believed to promote the efficient allocation of resources, allows countries to experience the benefits of economies of scale, facilitates the diffusion of knowledge, fosters technological progress and encourages competition.

As a result of these advantages, national and regional policy makers are putting in place institutional structures and programs that serve as platforms in boosting international trade in their national and regional economies. Policy makers of the CEMAC region for instance have put in place institutional structures and designed strategic programs in a bid to boost international trade within the CEMAC program. Such institutional structures include the Monetary Union of Central African States (UMAC) which is in charge of financial integration and the Economic Union of Central African States (UEAC) which is in charge of economic integration. Also, such strategic programs include the CEMAC Regional Economic Program and the CEMAC Economic and Financial Reform Program.

Designed in 2009, the CEMAC Regional Economic Program (PER) was put in place in order to accelerate trade and economic growth in the region. Also known as CEMAC's "Vision 2025", the Regional Economic Program is aimed at making CEMAC an emerging regional economic bloc where security, solidarity and good governance prevail at the service of human development.

Again, another major CEMAC regional program that was designed is the CEMAC Economic and Financial Reform Economic Program (CEMAC-PREF) that was developed in July 2016 in Malabo with the aim of implementing accelerated, vigorous and coordinated policy actions at both national and sub-regional levels, with the view of stabilizing the structural macroeconomic framework and transforming the economies of the subregion in order to strengthen their resilience and place them on the path of emergence.

Despite all these institutional structures and strategic programs put in place by Policy makers of the CEMAC trade bloc, bilateral trade flows within the region and economic prosperity within the entire region has not been encouraging.

According to UNCTAD Statistics (2019), when compared to other Regional Trade Arrangements in Africa, the value of merchandise trade for the CEMAC region is relatively smaller. In 2018 for instance, while CEMAC 
realized only 29,569 million US Dollars as value in merchandise trade, other trade blocs realized the following; Arab Maghreb Union (112,010 million US Dollars), the Community of Sahel Saharan States (209,283 million US Dollars), the Common Market for Eastern and Southern Africa (117,063 million US Dollars), the Economic Community of West African States (108,490 million US Dollars), the South African Customs

Union (108,955 million US Dollars) and the Southern African Development Community (188,201 million US Dollars).

This poor performance in CEMAC bilateral trade is corroborated by the poor performance in economic growth rates of CEMAC member Countries. Statistics from the World Bank's World Development Indicators (2019) indicate that the GDP growth rate of individual CEMAC countries and the region has a whole has been very mediocre. The statistics indicate that, since after the creation of CEMAC, apart from Equatorial Guinea that has witnessed a double digit GDP growth rate of over $14.217 \%$, others have witnessed just very slight improvements as is the case with Cameroon (0.853\%), Central African Republic (0.179\%) and Chad (3.909\%). Worst still, other countries have witnessed a drop in their GDP growth rate as is the case with Gabon $(-2.961 \%)$ and Congo Republic (-1.343). If we consider the CEMAC region as a whole, we observe that since after the creation of the CEMAC region, GDP growth rate has improved only by a single digit of 4.089 .

CEMAC's poor economic performance in terms of bilateral trade flows and GDP growth can be attributed to several obstacles. These obstacles are mostly institutional and political in nature.

In terms of the investment or business climate, statistics indicate that CEMAC does not have an attractive business climate. The Cameroonian business environment is far from been attractive. According to the World Bank's Doing Business Report (2020), It takes 81 days to register property, 14 days to start a business, 2.8 years to resolve insolvency, 800 days to enforce contracts, 163 hours to comply with import documents, 261 hours to comply with import procedures at the border, 66 hours to comply with export documents, 202 hours to comply with export procedures at the border and 64 days to get electricity. Also, according to the Doing Business Report (2020), Cameroon is ranked $167^{\text {th }}$ out of 190 countries in the Doing Business Index with an Ease of Doing Business score of 46.00492 out of 100 .

Also, Central African Republic's business climate is far from been attractive to business and trade. According to the Doing Business Report (2020), in the Central African Republic, it takes 4.8 years to resolve insolvency, 120 hours to comply with import documents, 121.7 hours to comply with import procedures at the border, 48 hours to comply with export documents and 48 hours to comply with export procedures at the border. Again, according to the Doing Business Report (2020), Central African Republic is ranked $184^{\text {th }}$ out of 190 countries in the Doing Business Index with a poor Ease of Doing Business score of 35.56 out of 100 .

Again, Congo Republic's business climate is far from been attractive to business and trade. According to the Doing Business Report (2020), in the Congo Republic, it takes 49.5 days to start a business, 54 days to register property, 560 days to enforce contracts and 3.3 years to resolve insolvency. Moreover, it takes 208 hours to comply with import documents, 397.3 hours to comply with import procedures at the border, 120 hours to comply with export documents and 276 hours to comply with export procedures at the border. Again, the Doing Business Report (2020) indicates that Congo Republic is ranked $180^{\text {th }}$ out of 190 countries in the Ease of Doing Business Index with a poor Ease of Doing Business score of 38.226 out of 100 .

Likewise, Equatorial Guinea's business climate is far from been attractive to business and trade. According to the Doing Business Report (2020), it takes 33 days to start a business, 23 days to register property, 475 days to enforce contracts, 240 hours to comply with import documents, 240 hours to comply with import procedures at the border, 154 hours to comply with export documents, 132 hours to comply with export procedures at the border and 160 days to get electricity. Also, the Doing Business Report (2020) ranks Equatorial Guinea $178^{\text {th }}$ out of 190 in the Doing Business Index with a poor Ease of Doing Business score of 40.536 out of 100.

Furthermore, Gabon has a very poor business climate. According to the Doing Business Report (2020), in Gabon, it takes 31 days to start a business, 72 days to register property, 1,160 days to enforce contracts, 5 years to resolve insolvency, 120 hours to comply with import documents, 84 hours to comply with import procedures at the border, 60 hours to comply with export documents, 96 hours to comply with export procedures at the border and 148 days to get electricity. The Doing Business Report (2020) also reveals that Gabon is ranked $169^{\text {th }}$ out of 190 countries in the Doing Business Index with a poor Ease of Doing Business score of 44.497 out of 100 .

Lastly, statistics indicate that Chad has a very poor business climate. According to the Doing Business Report (2020), in Chad, it takes 58 days to start a business, 44 days to register property, 743 days to enforce contracts, 4 years to resolve insolvency, 172 hours to comply with import documents, 242 hours to comply with import procedures at the border, 87 hours to comply with export documents, 106 hours to comply with export procedures at the border and 67 days to get electricity. Finally, according to the Doing Business Report, Chad is ranked $182^{\text {nd }}$ out of 190 countries in the Ease of Doing Business Index with a poor Ease of Doing Business score of 36.660 out of 100 .

Moreover, statistics from Transparency International (2019) indicate that corruption is endemic in the CEMAC region. The figures reveal the following; Gabon is ranked $123^{\text {rd }}$ out of 180 countries with a score of 
31/100, Cameroon and Central African Republic are both ranked $153^{\text {rd }}$ out of 180 countries each with a score of $25 / 100$, Congo Republic is ranked $165^{\text {th }}$ out of 180 with a score of $19 / 100$, Chad is ranked $162^{\text {nd }}$ out of 180 with a score of 20/100 and finally Equatorial Guinea is ranked $173^{\text {rd }}$ out of 180 countries with a score of 16 out of 100 .

Furthermore, statistics from the World Bank's World Governance Indicators reveal that the CEMAC region has a very poor governance record which may act as a detriment in boosting bilateral trade flows within the region. The World Governance Indicators is made up of six indicators which include Voice and Accountability, Political Stability and the Absence of Violence/Terrorism, Government Effectiveness, Regulatory Quality, Rule of Law and Control of Corruption. The indicators are ranked from 0 to 100 with 0 been the worst rank score and 100 been the best rank score.

In terms of Voice and Accountability, Cameroon, Gabon, Central African Republic, Congo Republic, Chad and Equatorial Guinea are ranked 18.23, 22.17, 14.78, 15.27, 8.37 and 2.46 respectively. In terms of Political Stability and the Absence of Violence/Terrorism, Cameroon, Gabon, Central African Republic, Congo Republic, Chad and Equatorial Guinea are ranked

8.57, 37.62, 0.23, 29.52, 8.10 and 43.81 respectively. In terms of Government Effectiveness,

Cameroon, Gabon, Central African Republic, Congo Republic, Chad and Equatorial Guinea are ranked 19.71, $18.75,2.88,10.10,6.73$ and 9.62 respectively. In terms of Regulatory Quality, Cameroon, Gabon, Central African Republic, Congo Republic, Chad and Equatorial

Guinea are ranked 20.19, 16.83, 6.73, 7.21, 11.54 and 4.81 respectively. In terms of Rule of

Law, Cameroon, Gabon, Central African Republic, Congo Republic, Chad and Equatorial Guinea are ranked $12.50,24.52,3.85,11.54,7.21$ and 6.73 respectively. Lastly, in terms of control of corruption, Cameroon, Gabon, Central African Republic, Congo Republic, Chad and Equatorial Guinea are ranked 11.06, 18.71, 10.58, 7.69, 6.73 and 2.40 respectively.

From all the data points, we see that none of the data points has even an average pass score of 50. Policy makers therefore have to design and implement measures that improve governance measures in the CEMAC region if they aspire to achieve economic prosperity in the CEMAC region.

Lastly, the CEMAC region has suffered a lot of economic stagnation and even economic decline due to political instability in the region. After having enjoyed several decades of political stability, for many years now Cameroon has been grappling with attacks by Boko Haram in the Far North, a Secessionist insurgency in the Anglophone regions as well as Rebel attacks in the East region. Such political instability acts as a serious impediment to the free flow of goods and services within the CEMAC region.

Also Central African Republic has been experiencing armed rebel conflicts over the years. On February 6, 2019, Government of the Central African Republic signed an African Union mediated peace agreement with fourteen armed groups. This agreement was endorsed by the

International Community and the African Union endorsed. The Mission of The United Nations Peacekeeping Force to Central Africa (MINUSCA) has been playing a very critical supportive role in the background.

Again, in November 2017, a ceasefire agreement was signed between the Congolese Government and representatives of the former rebels who had reignited a rebellion in the Department of Pool following the 2016 Presidential elections. Peace and security have gradually returned while the government and the International Community strive to consolidate the still fragile peace in the South of the country.

Lastly Chad is grappling with security challenges associated with conflicts in bordering countries. The main security challenge faced by Chad is the instability caused in the region by the Islamic sect Boko Haram.

In summary, institutional and political obstacles act as impediments to the growth of trade flows and economic growth in the CEMAC region. Policy makers need to take urgent and consistent actions in dismantling these obstacles so that the CEMAC region can also enjoy economic prosperity.

In this light, the following research question is answered in the study; what is the impact of CEMAC bilateral trade on the economic growth of Cameroon? This paper thus aims at examining the impact of CEMAC bilateral trade on the economic growth of Cameroon. Specifically, the study aims at examining the impact of trade flows (export plus import flows), labour force, human capital, investment in fixed capital and the formation of the CEMAC trade bloc on the Gross Domestic Product (GDP) of Cameroon. More especially, very little literature exists on the impact of CEMAC bilateral trade on the economic growth of Cameroon thereby creating a vacuum which the current paper stands to fill. The rest of the paper is structured to handle literature review, methodological issues, empirical results and policy recommendations.

\section{Literature Review}

The principal theoretical inspiration for this study is the Neo-Classical Growth model attributed to Solow (1956). The economic form of the Solow model in its simplest augmented form that includes human capital (H) is given as;

$\mathrm{Y}=\mathrm{AHL}^{(1-\alpha)} \mathrm{K}^{\alpha}$

Where $\mathrm{A}=$ technology or productivity which is assumed to be an endogenous constant 
$\mathrm{H}=$ Human capital (education and training)

$\mathrm{L}=$ Number of persons physically engaged in work

$\mathrm{K}=$ Physical capital

If we use EDU to represent education and training, LAB, to represent labour force and INFC to represent investment in fixed capital, equation (1) in econometric form is given as

$\mathrm{Y}_{\mathrm{ijt}}=\alpha_{0}+\alpha_{1}$ EDU $+\alpha_{2} \mathrm{LAB}+\alpha_{3}$ INFC $+\mu_{\mathrm{ijt}}$

Where $\mathrm{Y}_{\mathrm{ijt}}$ is GDP at time for any given country $\mathrm{i}, \mathrm{j}$ at time $\mathrm{t}$

EDU $=$ Human capital (education and training)

$\mathrm{LAB}=$ labour force

INFC $=$ Investment in fixed physical capital

$\mu_{\mathrm{ijt}}=$ error term

$\alpha 0=$ constant term with $\alpha_{1}, \alpha_{2}, \alpha_{3}>0$

From equation (2), additional variables that affect economic growth such as total trade (sum of exports and imports) and the formation of a regional trade agreement (trade bloc) could be included.

$\mathrm{Y}_{\mathrm{ijt}}=\alpha_{0}+\alpha_{1} \mathrm{EDU}+\alpha_{2} \mathrm{LAB}+\alpha_{3} \mathrm{INFC}+\alpha_{4} \mathrm{TTXM}+\alpha_{5} \mathrm{RTA}+\mu_{\mathrm{ij} t}$

Where $\mathrm{EDU}=$ Human capital (education and training)

$\mathrm{LAB}=$ labour force

$\mathrm{INFC}=$ Investment in fixed capital

TTXM $=$ Total trade flows (Exports plus imports)

RTA $=$ Regional Trade Agreement dummy that takes the value 0 before the formation of the Regional Trade Agreement and takes the value 1 after the formation of the Regional Trade Agreement.

$\mu_{\mathrm{ijt}}=$ error term $\alpha_{0}=$ constant term, with $\alpha_{1}, \alpha_{2}, \alpha_{3}>0, \alpha_{4}>0$ and $\alpha_{5}$ is the RTA dummy which takes the value 0 for the time period before the formation of the RTA and takes the value 1 for the time period after the formation of the RTA.

In summary, we can assert that the Solow model serves as a solid theoretical framework that captures the link between international trade and economic growth. In simple terms, international trade serves as a mechanism for the mobility of factors of production such as labour, capital, knowledge, information, education and training, technology, goods and services from one economy to another with the end result been the convergence between countries as a result of an improvement in the economic growth in the economies of the various trading partners. Also, the formation of Regional Trade Agreements also known as trade blocs serve as excellent platforms that promote trade. The removal of all forms of trade barriers in Regional Trade Agreements (trade blocs) facilitates the movement of capital, labour, knowledge, information, education and training, goods and services from one economy to another with the end result been the convergence between countries as a result of an improvement in the economic growth in the economies of the various trading partners.

A number of empirical studies such as those of Zahonogo (2017), Hye et al. (2016), Brueckner and Lederman (2015), Asfaw (2014), Azeez et al. (2014), Nowbutsing (2014), Edoumiekumo and Opukri (2013), Atoyebi et al. (2012), Emeka et al. (2012), Omoju and Adesanyo (2012), Obadan and Okojie (2010) and Vlastou (2010) amongst others reveal that international trade has a positive impact on economic growth.

Zahonogo (2017) had as main objective to investigate the effect of trade on economic growth in developing countries with special focus on Sub-Saharan African countries for a time frame covering the period from 1980 to 2012. Using the Pooled Mean Group Estimation Technique, the results indicate that a trade threshold exists below which greater trade openness has beneficial effects on economic growth and above which the trade effect on economic growth declines. The study recommends that Sub-Saharan African countries must have effective trade openness particularly by productively controlling import levels in order to boost their economic growth through international trade.

Hye et al. (2016) aimed to determine the long run relationship between trade and economic growth in China for the time period from 1975 to 2009 . Using the rolling window regression method and the autoregressive distributed lag (ARDL) co-integration technique, the results indicate that trade openness is positively related to economic growth both in the long run and in the short run. They recommend that a more comprehensive policy to promote trade openness should be encouraged in China.

Brueckner and Lederman (2015) examined the relationship between trade and economic growth in SubSaharan Africa. Using Instrumental Variables Approach to a panel of forty one countries, the paper shows that trade openness has a significant positive effect on economic growth. Specifically, the results indicate that a one percentage point increase in the ratio of trade over GDP is associated with a short-run increase in growth of approximately $0.5 \%$ in a given year with the cumulative long-run effect on the level of GDP per capita reaching about $2 \%$. The study recommends that policy-makers should adopt policies that are geared towards improving the trade openness of Sub-Saharan African economies.

Asfaw (2014) assessed the link between trade and economic growth in forty-seven SubSaharan African 
countries over the time period from 2000 to 2008. Using panel data estimation techniques, the results estimated support the claim that openness to international trade stimulates both economic growth and investment. In addition, the study found that trade policies such as average weighted tariff and real effective exchange rate have both direct and indirect impacts on economic growth. The study recommends that more practical actions should be undertaken to boost trade in these Sub-Saharan African Countries for this will go a long way to boost economic growth.

Azeez et al. (2014) examined the effect of trade on the economic growth of Nigeria in the $21^{\text {st }}$ Century for the time period from 2000 to 2012. Using Ordinary Least Square (OLS) estimation technique, the results revealed that international trade has a significant positive impact on economic growth. Specifically, the variables imports, exports and trade openness which are used as proxies of international trade all had a significant effect on the economic growth of Nigeria. The study recommends that the Nigerian government should reduce over-dependence on oil exports and increase and diversify its export base in order to earn more revenue.

Nowbutsing (2014) analysed the impact of trade on the economic growth of fifteen Indian Ocean Rim Countries over the time period 1997 to 2011. Using the Fully Modified Ordinary Least Square (FMOLS) to estimate the model, the results indicate that the three measures (trade as percentage of GDP, exports as a percentage of GDP and Imports as a percentage of GDP) that were used as measures of trade openness all had a positive impact on the economic growth of these countries. The study therefore recommends that policy measures that improve on the trade openness of these countries should be encouraged for this will go a long way to boost economic growth.

Edoumiekumo and Opukri (2013) examined the contributions of international trade to economic growth in Nigeria using time series data for a period of twenty seven years. Making use of the Augmented Dickey-Fuller (ADF) test, Ordinary Least Square (OLS) Statistical technique, Johansen Co-integration test and Granger Causality test, the results show that a positive relationship exists between economic growth, export and import. The overall model was significant at five percent. Finally, they used the Granger Causality test to study the causality between the variables and realized a unidirectional relationship. They recommend that Nigeria needs to increase and diversify her export goods in order to enjoy more of the benefits of international trade.

Atoyebi et al. (2012) examined the impact of international trade on the economic growth of Nigeria from 1970 to 2010. Using the Phillips Peron Unit root test and the Johansen Cointegration test, the empirical investigations revealed that the variables export, foreign direct investment and exchange rate were positively related to real GDP and were statistically significant at 5\%. However, other variables such as import, inflation rate and trade openness had a negative impact on real GDP. They recommended that the Nigerian government should design appropriate strategy by diversifying her economy through export promotion, stimulating foreign direct investment and ensuring exchange rate stability in order to boost the economic growth of the Nigerian economy.

Emeka et al. (2012) evaluates the role of trade on the economic growth of Nigeria for the period 1970 to 2008. Using a combination of bivariate and multivariate models, the outcome of the empirical analysis indicated that exports and foreign direct investment inflows have positive and significant impact on the economic growth of Nigeria. The study recommends amongst others that there should be a congruence of export and fiscal policies towards a greater diversification of non-oil exports by the Nigerian government in order to attain the desired growth prospects of external trade.

Omoju and Adesanyo (2012) examined the impact of trade on the economic growth of Nigeria using data from 1980 to 2010. Making use of the Ordinary Least Square (OLS) technique, the results show that trade, foreign direct investment, government expenditure and exchange rate have a significant positive impact on the economic growth of Nigeria. Based on the findings, the study recommends that the government should create an enabling environment that would facilitate trade, encourage foreign direct investment, improving government expenditure and ensuring exchange rate stability for this will go a long way in boosting economic growth in Nigeria.

Obadan and Okojie (2010) examined the impact of trade on the economic growth of Nigeria using time series data for the period 1980 to 2007. Using Ordinary Least Square (OLS) technique, the results showed that trade openness had a positive impact on the economic growth of Nigeria. The study therefore recommended that Nigeria should diversify her export base to include agricultural exports and solid minerals instead of depending solely on petroleum.

Vlastou (2010) investigated the relationship between trade and openness and economic growth for a sample of thirty four African Countries over the period 1960 to 2003. Using the dynamic Ordinary Least Squares techniques and making use of novel time series techniques concentrated around panel unit root, panel cointegration and panel causality tests, the empirical findings reveal a negative and significant impact of trade openness on economic growth. The study recommends that African economies should redouble their efforts in designing and implementing policies that promote trade for this will go a long way in boosting long run economic growth.

\section{Methodological Issues}

The study covers a time period of forty six years from 1972 to 2018. (Twenty one years before the formation of 
the CEMAC trade bloc-1972 to 1993, and twenty five years after the formation of the CEMAC trade bloc- 1994 to 2018).

Data for gross domestic, total labour force, investment in fixed capital and investment in human capital (education and training) are obtained from the World Bank's World Development Indicators (2020). Also data for bilateral trade between trade and other CEMAC member countries is obtained the IMF's Direction of Trade Statistics (2020). The CEMAC dummy takes the value 0 for the twenty-one year period before the formation of the CEMAC trade bloc (1972 to 1993) while the CEMAC dummy takes the value 1 for the twenty-five year period after the formation of CEMAC trade bloc (1994 to 2018).

The model for the impact of CEMAC bilateral trade on the economic growth of Cameroon draws its inspiration from the theoretical foundations of the Solow Neo Classical growth model (1956) that was augmented by Mankiw et al. (1992). It also draws inspiration from the empirical work of Khadaroo and Seetenah (2008). The model for the impact of bilateral trade on the economic growth of Cameroon is therefore given as;

$\mathrm{Y}_{\mathrm{ijt}}=\alpha_{0}+\alpha_{1} \mathrm{LAB}+\alpha_{2} \mathrm{INFC}+\alpha_{3} \mathrm{TTXM}+\alpha_{4} \mathrm{EDU}+\alpha_{5} \mathrm{CEMAC}+\mu_{\mathrm{ijt}}$

Where $\mathrm{LAB}=$ labour force, $\mathrm{INFC}=$ Investment in fixed capital, TTXM $=$ Total bilateral trade (Exports plus imports) between Cameroon and other CEMAC member Countries, EDU= Human capital (education and training) and $\mathrm{CEMAC}=\mathrm{CEMAC}$ dummy that takes the value 0 for time period before the formation of the CEMAC trade bloc and takes the value 1 for the time period after the formation of the CEMAC trade bloc

$\mu_{\mathrm{ijt}}=$ error term, $\alpha_{0}=$ constant term, with $\alpha_{1}, \alpha_{2}, \alpha_{3}>0, \alpha_{4}>0$ and $\alpha_{5}$ is the CEMAC dummy which takes the value 0 for the time period before the formation of CEMAC (1972 to 1993) and it takes the value 1 for the time period after the formation of the CEMAC trade bloc (1994 to 2018).

The main estimation technique used in this study is the Poisson Pseudo Maximum Likelihood (PPML) estimation technique. It is chosen over traditional gravity estimation techniques such as the Ordinary Least Squares (OLS) technique because it is consistent in the presence of fixed effects, it naturally includes observations for which the observed trade value is zero and it has the inbuilt capacity to take care of the problems of heteroskedasticity. The PPML estimation technique has been used extensively in the estimation of gravity equations by authors such as Bosquet and Boulhol (2015), Egger and Tarlea (2015), Dai et al. (2014), Lin (2013), Yotov (2012), de Souza (2012), Egger and Larch (2011), Head et al. (2010), Shepherd (2010) and Tenreyro (2007) amongst others.

\section{PPML Regression Results and Discussion of Findings}

Table 1: PPML Regression Results on the Impact of CEMAC Bilateral Trade on the Economic Growth of Cameroon

Number of parameters: 6

Number of observations: 235

Pseudo log-likelihood: -573.46306

R-squared: .89253579

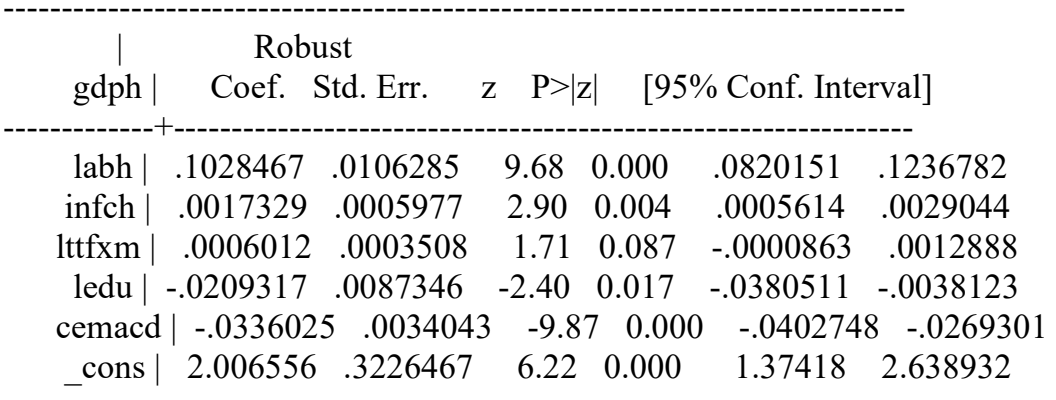

Source: Author (2020)

Firstly, the regression results reveal that home labour force has a positive and significant impact on the GDP of Cameron. The results are in accordance with the Solow Neo-Classical Theory of Economic Growth that postulates that international trade favours the free movement of unskilled and skilled labour between countries thereby contributing in the GDP of the various trading partners. The results corroborate with the results of other authors such as Zahonogo (2017) and Hye et al. (2016) amongst others.

However, labour values have only a minimal impact on its GDP. Precisely, if labour values increase by one unit, it will lead to a .1028467 increase in Cameroon's GDP. It is therefore imperative that Cameroonian authorities put in place measures that facilitate the free movement of skilled and unskilled labour between CEMAC member countries for this will serve as physical manpower as well as act as a channel in the transfer of technical and professional skills and competencies for the mutual benefit of the CEMAC member countries and for the Cameroonian economy in particular. 
Next, PPML regression results for home infrastructure reveal that infrastructure has a positive and significant impact on the GDP of Cameroon. The results are in accordance with economic a priori expectation since transport infrastructure (road, railway and airway) acts as channel for the movement of goods, services, technology and labour between CEMAC member countries. The results also corroborate with the results of other authors such as Zahonogo (2017) and Hye et al. (2016) amongst others.

However, the results reveal that the impact on home infrastructure on the GDP of Cameroon is very minimal. Precisely, a unit increase in infrastructure will lead to a .0017329 increase in the GDP of Cameroon. It is therefore imperative that Cameroonian authorities invest in their national as well as in regional transport networks. The interconnectedness of CEMAC member countries by road, railway, maritime and air transport networks is vital for the free movement of goods, services, information, capital and labour within national boundaries and across CEMAC member countries.

In addition, PPML regression results for Cameroon's total bilateral trade with other CEMAC member States reveal that total trade has a positive but insignificant impact on the GDP of Cameroon. These results are not in conformity with economic a priori expectation. According to the Neo-classical Growth Theory, international trade facilitates the free movement of goods and services, information, capital and labour and this has the potential of boosting economic growth. The results do not corroborate with the results of other authors such as Zahonogo (2017) and Hye et al. (2016) amongst others.

Also, the positive impact of trade on the economic growth of Cameroon is very minimal. Precisely, a $1 \%$ increase in total trade will lead to a $.0006012 / 100=.000006012$ unit increase in the GDP of Cameroon. It is therefore important that Cameroonian authorities design and implement measures that facilitate trade flows between CEMAC member countries. As already mentioned, these measures could be in the form of improving transport infrastructure networks, good governance measures as well as improving the business climate.

Furthermore, PPML regression results for Cameroon's education values reveal that education has a negative but significant impact on the economic growth of the Cameroon. The results are not in conformity with economic a priori expectation. Education necessitates the acquisition and transfer of knowledge, skills and competencies. The transfer of acquired knowledge, skills, information, technology and competencies across CEMAC member countries will further boost the economic growth of these CEMAC member countries. In addition, the results do not corroborate with other empirical works such as those of Zahonogo (2017) and Hye et al. (2016) amongst others.

Precisely, a 1\% increase in home country education levels will lead to a $-.0209317 / 100=-.000209317$ reduction in the GDP of Cameroon. It is therefore imperative that Cameroonian authorities invest more resources in the education sector. More importantly, focus should be placed in the acquisition and transfer of technical and technological skills as well as the professionalization of education. This will go a long way in boosting the economic growth of Cameroon as well as other CEMAC member Countries.

Lastly, the CEMAC dummy has a negative but significant impact on the economic growth of Cameroon. The results are not in accordance with economic a priori expectation. According to Lynch (2010), regional trade agreements (trade blocs) are expected to increase market access in member countries, increase competition, promote trade liberalization and encourage the free movement of goods, services, capital, labour, skills and technology.

The results also do not corroborate with the results of other authors such as Alleyne and Lorde (2014) and Garcia et al. (2013) who found out that the creation of trade blocs rather acts as platforms that boost bilateral regional trade.

Precisely, since after the creation of the CEMAC trade bloc, the GDP of Cameroon has decreased by -.0336025. It is therefore vital that Cameroonian authorities and policy makers of the CEMAC region in general re-energize their efforts in designing and implementing policies that facilitate the free movement of goods and services within the CEMAC region. As already mentioned, such measures include the complete harmonization of regional financial policies, socio-economic policies, trade policies as well as trade policies amongst other policies. Other pertinent measures include the improvement of regional transport infrastructure, improving the business climate and relaxing eliminating any restrictions that hinder the free movement of people, goods and services across the borders of member countries.

Finally the R-squared value of 0.89253579 reveals that over $89 \%$ of the data fits the regression model. The R-squared value of 0.89253579 therefore indicates a good fit for the model.

\section{Policy Recommendations}

Firstly, it is imperative that Cameroonian authorities put in place measures that facilitate the free movement of skilled and unskilled labour between CEMAC member countries for this will serve as physical manpower as well as act as a channel in the transfer of technical and professional skills and competencies for the mutual benefit of the CEMAC member countries and for the Cameroonian economy in particular.

Next, it is imperative that Cameroonian authorities invest in their national as well as in regional transport networks. The interconnectedness of CEMAC member countries by road, railway, maritime and air transport 
networks is vital for the free movement of goods, services, information, capital and labour within national boundaries and across CEMAC member countries.

Again, it is important that Cameroonian authorities design and implement measures that facilitate trade flows between CEMAC member countries. As already mentioned, these measures could be in the form of improving transport infrastructure networks, good governance measures as well as improving the business climate.

Moreover, it is imperative that Cameroonian authorities invest more resources in the education sector. More importantly, focus should be placed in the acquisition and transfer of technical and technological skills as well as the professionalization of education. This will go a long way in boosting the economic growth of Cameroon as well as other CEMAC member Countries.

Finally, it is vital that Cameroonian authorities and policy makers of the CEMAC region in general reenergize their efforts in designing and implementing policies that facilitate the free movement of goods and services within the CEMAC region. As already mentioned, such measures include the complete harmonization of regional financial policies, socio-economic policies, trade policies as well as trade policies amongst other policies. Other pertinent measures include the improvement of regional transport infrastructure, improving the business climate and relaxing eliminating any restrictions that hinder the free movement of people, goods and services across the borders of member countries.

\section{Conclusion}

Despite the existing measures put in place by policy makers of the CEMAC region to boost bilateral trade and economic growth in the region, bilateral trade in the CEMAC region has a positive though insignificant impact on the economic growth of Cameroon. It is therefore imperative that the various economic agents of the CEMAC region ensure a favourable investment and political climate for this will go a long way in boosting bilateral trade within the CEMAC bloc thereby leading to economic growth in the CEMAC bloc through the multiplier effect.

\section{References}

Alesina, A., Spolaore, E., Wacziarg, R., 2000. Economic integration and political disintegration. American Economic Reviw. 90 (5), 1276-1296

Almeida, R., Fernandes, A., 2008. Openness and technological innovations in developing countries: evidence from firm-level surveys. Journal of Development Studies. 44 (5), 701- 727.

Asfaw, H.A (2014). Trade policy and economic growth in Sub-Saharan Africa: A panel data approach. American Journal of Trade and Policy, 1, 94-101.

Atoyebi et al. (2012). Foreign Trade and Economic Growth in Nigeria: An Empirical Analysis. American Academic and Scholarly Research Journal Vol. 4, N0. 5.

Azeez et al. (2014). Effect of International Trade on Nigerian Economic Growth: The $21^{\text {st }}$ Century Experience. Journal of Economics, Commerce and Management Vol. 11, N0. 10.

Baldwin, R.E., Braconier, H., Forslid, R., 2005. Multinationals, endogenous growth, and technological spillovers: theory and evidence. Review of International Economics 13 (5), 945- 963.

Barro, R.J., Sala-i-Martin, X., 1997. Technological diffusion, convergence, and growth. Journal of Economic Growth 2 (1), 2-26.

Bond, E.W., Jones, R.W., Ping., 2005. Economic take-offs in a dynamic process of globalization. Review of International Economics 13 (1), 1-19.

Bosquet, C., Boulhol, H., 2015. What is really puzzling about the "distance puzzle"? Review of World Economy, volume 151, issue 1, pp. 1-21.

Brueckner, M., and Lederman, D. (2015). Trade openness and economic growth: Panel data evidence from SubSaharan Africa. Economica, 82, 1302-1323.

Dai, M., Yotov, Y. V., Zylkin, T. 2014. On the Trade-diversion Effects of Free Trade Agreements. Economics Letters, volume 122, issue 2, pp. 321-325.

de Sousa, J., 2012 . The currency union effect on trade is decreasing over time. Economics Letters, Volume 117, pp. 917-920.

Edoumiekumo, S.G. \& Opukri, C.O. (2013). Economic Growth Factor in Nigeria: The Role of Global Trade. American Journal of Humanities and Social Sciences, Vol. 1, No. 2, 51-55

Egger, P., Larch, M., 2011. An assessment of the Europe agreements' effects on bilateral trade, GDP, and welfare. European Economic Review, volume 55, pp. 263-279.

Egger, P. H., Tarlea, F., 2015. Multi-way clustering estimation of standard errors in gravity models. Economics Letters, Volume 134, pp. 144-147.

Emeka, E.J., Frederick, I. \& Peter, A. (2012). Macroeconomic Impact of Trade on Nigerian Growth: An Empirical Evaluation. Research Journal of Business Management and Accounting, Vol. 1(4), 079-083

Grossman, G. and E. Helpman (1991), Innovation and Growth in the Global Economy, Cambridge, MA: MIT Press. 
Hye, Q. M., Wizarat, S., \& Lau, W.-Y. (2016). The impact of trade openness on economic growth in China: An empirical analysis. The Journal of Asian Finance, Economics and Business, 3, 27-3

Solow, R. M. (1956) 'A contribution to the theory of economic growth', The Quarterly Journal of Economics, 70(1), 65-94.

Lin, F., 2013. Are distance effect really a puzzle? Economic Modelling, volume. 31, pp. 684689.

Nowbutsing, B. M. (2014). The impact of openness on economic growth: Case of Indian Ocean rim countries. Journal of Economics and Development Studies, 2, 407-427.

Obadan and Okojie (2010). An Empirical Analysis of the Impact of trade on Economic Growth in Nigeria. Jos Journal of Economics, Vol.4, No.1

Omoju, O. \& Adesanya, O. (2012). Does Trade Promote Growth in Developing Countries? Empirical Evidence from Nigeria. International Journal of Development and Sustainability, Vol. 1, No. 3, 743-753

Shepherd, B., 2010. Geographic Diversification of Developing Country Exports. World Development, Volume 38, issue 9 , pp. 1217-1228.

Tenreyro, S., 2007. On the trade impact of nominal exchange rate volatility. Journal of Development Economics, volume 82, pp. 485-508.

Vlastou, I. (2010). Forcing Africa to open up to trade: Is it worth it? The Journal of Developing Areas, 44, $25-39$.

Yotov, Y. V., 2012. A simple solution to the distance puzzle in international trade. Economics Letters, Volume 117, pp 794-798.

Zahonogo, P. (2017) "Trade and Economic Growth in Developing Countries: Evidence from SubSaharan Africa", Journal of African Trade, 3(1-2), 41-56. 